\title{
Capacity building of women of Mangali village, Hisar through time management and entrepreneurial training for making bead crafts
}

\author{
Ekta Melkani, Kiran Singh and Manju Mehta
}

Received: 27.01.2020; Revised: 26.03.2020; Accepted: 11.05 .2020

See end of the paper for authors' affiliations

\section{Ekta Melkani}

Department of Family Resource

Management, C.C.S. Haryana Agricultural University, Hisar

(Haryana) India

Email : ektamelkani@gmail.com
ABSTRACT : The plight of the women workers is reported worse in the small scale industries. Bead making, a small scale enterprise, is commonly practiced in North-Western part of Haryana where bead making from wood is the main source of livelihood for more than 70 per cent of the households in Mangali village. All the family members have been involved in various activities of bead making. However, women's involvement was higher in making beads and string (mala) making (Gandhi et al., 2017) who spend 8-12 hours daily for bead string making at one rupee per string. Seasonal calendar and activity profiles of 50 purposively selected women from Surtiya Panchayat of Mangali village were recorded for the assessment of the working hours of the women involved in bead string making. The work-rest ratio of the average respondents in minutes was calculated to be 20:3, which was not satisfactory for the long hours sitting work. Trainings with time management, bead products like jewelry making, curtains, bead vases, and other bead craft techniques was given to the women for eight months at intermittent intervals. The similar work is recommended to be introduced on large scale and a proper channel can be devised to sell the products and benefit the enterprise. More time management trainings need to happen at village levels to reduce the unnecessary drudgery of the rural women and employ their precious time in quality and productive works. This will ensure that the diverse designs and market colour trends would have wide range of customers resulting in good returns for the bead making enterprise.

KEY WORDS: Village women, Intervention, Marketing, Time management, Bead products, Income generation

- HOW TO CITE THIS PAPER : Melkani, Ekta, Singh, Kiran and Mehta, Manju (2020). Capacity building of women of Mangali village, Hisar through time management and entrepreneurial training for making bead crafts. Asian J. Home Sci., 15 (1) : 130-133, DOI: 10.15740/HAS/AJHS/15.1/130-133. Copyright@ 2020: Hind Agri-Horticultural Society. 